\title{
Prevalence, identification of virulence factors, O-serogroups and antibiotic resistance properties of Shiga-toxin producing Escherichia coli strains isolated from raw milk and traditional dairy products
}

Reza Ranjbar ${ }^{1}$, Farhad Safarpoor Dehkordi ${ }^{2}$, Mohammad Hossein Sakhaei Shahreza ${ }^{3 *}$ and Ebrahim Rahimi ${ }^{4,5}$

\begin{abstract}
Background: Shiga-toxigenic Escherichia coli strains are one of the most important foodborne bacteria with an emergence of antibiotic resistance. Foodborne STEC strains are mainly associated with presence of certain virulence factors and O-seogroups. The present investigation was done to study the distribution of virulence factors, O-serogroups and antibiotic resistance properties of Shiga-toxigenic Escherichia coli isolated from milk and dairy products.
\end{abstract}

Methods: Six-hundred samples were randomly collected and immediately transferred to laboratory. All samples were cultured and E. coli strains were isolated. STEC strains were identified based on the presence of putative virulence factors and subtypes. STEC isolates were subjected to multiplex PCR and disk diffusion methods.

Results: One-hundred and eighty-one out of 600 samples (30.16\%) harbored E. coli. Prevalence of STEC strains was 10.66\%. O157 (43.75\%) and O26 (37.50\%) were the most frequently identified serogroups. Aac(3)-IV (100\%), CITM (96.87\%) and tetA (76.56\%) were the most commonly detected antibiotic resistance genes. STEC strains had the highest prevalence of resistance against ampicillin (100\%), gentamicin (100\%) and tetracycline (96.87\%).

Conclusions: Kashk and dough were negative for presence of $E$. coli strains. High prevalence of resistant-O157 strains and simultaneous presence of multiple virulence factors pose an important public health problem regarding the consumption of raw milk and dairy products.

Keywords: Shiga toxin producing Escherichia coli, Molecular characterization, Antibiotic resistance

\section{Background}

Billions of people consuming milk and dairy products every day. Milk and dairy products are full from valuable nutritional factors such as proteins, lipids, minerals, and vitamins. Researches showed that consumption of milk and dairy products is useful for human $[1,2]$. There are several types of dairy products such as cheese, cream,

\footnotetext{
* Correspondence: Dr.mh_sakhaieshahreza@yahoo.com

${ }^{3}$ Doctor Veterinary Medicine, Faculty of Veterinary Medicine, Shahrekord

Branch, Islamic Azad University, Shahrekord, Iran

Full list of author information is available at the end of the article
}

butter, yoghurt, and ice cream, with high beneficial effects for human health $[3,4]$. Kashk and dough are two important traditional dairy products in Iran and some other sites of the world. Kashk comes in liquid or dried forms and is traditionally made with the milk left over from cheese-making. Dough is a popular salty yogurt-based beverage amongst the Iranian people $[3,4]$. Based on the high consumption rate of milk and dairy products, it is important to ensure from the microbial quality of these types of food samples [5].

Escherichia coli (E. coli) strains are one of the most important cause of foodborne diseases al-around the world

(c) The Author(s). 2018 Open Access This article is distributed under the terms of the Creative Commons Attribution 4.0 International License (http://creativecommons.org/licenses/by/4.0/), which permits unrestricted use, distribution, and 
[5-7]. Milk and dairy products are one of the main sources of transmission of the E. coli strains into the human [5-7]. $E$. coli is a Gram-negative, non-sporulating, flagellated, rod-shaped and facultative anaerobic bacterium which belongs to Enterobacteriaceae family. Enterohemorrhagic $E$. coli (EHEC) strains are a subtype of the Vero (Shiga) toxin (Vtx or Stx)-producing E. coli (VTEC or STEC) $[5,6,8]$. EHEC bacteria are causative agents of severe syndromes including Hemolytic Uremic Syndrome (HUS), Thrombotic Thrombocytopenic Purpura (TTP), Hemorrhagic Colitis (HC) and bloody and non-bloody diarrhea $[5,6,9]$.

E. coli strains isolated from milk and dairy products harbored the high prevalence of intimin (eaeA), Vero or Shiga toxins ( $v t \times 1$ and $v t \times 2$ or st $x 1$ and st $x$ ) and hemolysin ( hly $A)$. These factors can cause bacterial adhesion and invasion into the intestinal epithelial cells which cause severe attaching-effacing (A/E) lesions [9-11]. Attaching and effacing lesions are mainly caused by certain types of the STEC bacteria called Attaching-Effacing E. coli (AEEC) [9-11]. Expression of the eae gene is the main factor for occurrence of A/E lesions [9-11].

Occurrence of foodborne diseases caused by this bacterium are mainly occurred due to the activity of certain O-serogroups including non-O157 (O103, O26, O113, O91, O145, O111, O121, O128 and O45) and also $\mathrm{O} 157[5,6,12]$.

STEC strains are mainly resistant against several types of antibiotics. Documented data revealed that STEC strains isolated from milk and dairy products and also other types of food samples harbored the high prevalence of resistance against different types of antibiotics including aminoglycosides, fluoroquinolone, tetracyclines, trimethoprim, ampicillin, cephalothin, sulfonamides, gentamicin and chloramphenicol [5-13]. Molecular epidemiological researches showed that presence of certain antibiotic resistance genes including the genes that encode resistance against fluoroquinolone (qnr), trimethoprim ( $d f r A 1)$, cephalothin (blaSHV), tetracycline (tetA and tetB), ampicillin (CITM), gentamicin (aac(3)-IV), sulfonamide (sul1), chloramphenicol (cat1 and $c m l A$ ), aminoglycosides (aadA1), and erythromycin (ereA) is the most important reason for occurrence of antibiotic resistance in STEC strains [5-13].

According to an uncertain role of STEC strains in milk and dairy products and deficiency of similar microbiological and epidemiological surveys in Iran, the current examination was done to molecular characterization of O-serogroups, virulence genes and antibiotic resistance properties of STEC bacteria recovered raw milk and traditional dairy products.

\section{Methods}

\section{Samples and Escherichia coli identification}

From March 2015 to March 2016, a total of 600 different types of raw milk and traditional dairy product samples including raw bovine $(n=70)$, raw ovine $(n=60)$, raw caprine $(n=60)$, raw buffalo $(n=40)$ and raw camel $(n=$ 30) milk samples and traditional cheese $(n=50)$, yoghurt $(n=60)$, kashk $(n=50)$, dough $(n=50)$, butter $(n=40)$, cream $(n=40)$ and ice-cream $(n=50)$ samples were randomly collected from Isfahan province, Iran. Samples collection was done according to the instruction introduced by International Dairy Federation [14]. Samples $(100 \mathrm{~mL})$ were transferred to laboratory at $4{ }^{\circ} \mathrm{C}$. All food samples showed normal physical characters including odor, color and consolidation.

Twenty-five milliliters of raw milk samples and $25 \mathrm{mg}$ of homogenized dairy products were added to sterilized tubes containing $225 \mathrm{ml}$ of Buffered Peptone Water (BPW, Merck, Germany) and hatched aerobically at $37^{\circ} \mathrm{C}$ for $24 \mathrm{~h}$. Then, samples were cultured on $5 \%$ sheep blood and MacConkey agar (Merck, Germany) media and incubated at $37{ }^{\circ} \mathrm{C}$ for $24 \mathrm{~h}$. Colonies with the typical color and appearance of $E$. coli were picked and streaked again on blood agar plates and re-streaked on EMB agar (Merck, Germany). All plates were further incubated for $24 \mathrm{~h}$ at $37{ }^{\circ} \mathrm{C}$. The green metallic sheen colonies were considered as E. coli. The presumptive colonies were biochemically tested for growth on triple sugar iron agar (TSI) and lysine iron agar (LIA), oxidative/fermentative degradation of glucose, citrate utilization, urease production, indol fermentation, tryptophan degradation, glucose degradation (methyl red test) and motility.

\section{PCR confirmation of $E$. coli isolates}

Colonies were further confirmed using the 16S rRNA-based Polymerase Chain Reaction (PCR) according to the method described previously [15]. Bacterial strains were subcultured overnight in Luria-Bertani broth (Merck, Germany) and further incubated for $48 \mathrm{~h}$ at $37^{\circ} \mathrm{C}$. Genomic DNA was extracted from bacterial colonies using the DNA extraction kit (Thermo Fisher Scientific, St. Leon-Rot, Germany) according to manufacturer's instruction. DNA quality and concentration were examined using the spectrophotometer [16]. The $10 \mathrm{ml}$ bacterial DNA extract and controls were amplified with $0.5 \mathrm{mM}$ primers (Forward: 5'-AGTTTGATCCTGGCTCAG-3' and Reverse: 5'AGGCCCGGGAACGTATTCAC-3') (1343 bp) [15], $200 \mathrm{mM}$ of each dNTP (Thermo Fisher Scientific, St. Leon-Rot, Germany), $2 \mathrm{mM} \mathrm{MgCl} 2,10 \mathrm{mM} \mathrm{KCl} \mathrm{PCR}$ buffer and 1.0 U Taq polymerase (Thermo Fisher Scientific, St. Leon-Rot, Germany). The DNA was amplified in a programmable thermal cycler (Eppendorf, Mastercycler $^{\bullet}$ 5330, Eppendorf-Netheler-Hinz GmbH, Hamburg, Germany) PCR device using the following protocol: $94{ }^{\circ} \mathrm{C}$ for $5 \mathrm{~min}, 40$ cycles of $94{ }^{\circ} \mathrm{C}$ for $1 \mathrm{~min}$, $55{ }^{\circ} \mathrm{C}$ for $1 \mathrm{~min}, 72{ }^{\circ} \mathrm{C}$ for $2 \mathrm{~min}$, and final $72{ }^{\circ} \mathrm{C}$ for 5 min. 


\section{Detection of virulence factors, O-serogroups and antibiotic resistance genes}

Table 1 indicates list of primers and PCR conditions used for detection of $\mathrm{O}$-serogroups, virulence genes and antimicrobial resistant genes [17, 18]. Fifteen microliters of amplified PCR products were subjected to electrophoresis in a $1.5 \%$ agarose gel in $1 \mathrm{X}$ TBE buffer at $80 \mathrm{~V}$ for $30 \mathrm{~min}$, stained with SYBR Green (Thermo Fisher Scientific, St. Leon-Rot, Germany) [17, 18]. All runs included a negative DNA control consisting of PCR grade water and strains of $E$. coli O157:K88 ac:H19, CAPM 5933 and $E$. coli $\mathrm{O} 159: \mathrm{H} 20$, CAPM 6006 were used as positive controls.

\section{Disk diffusion test}

Antibiotic resistance pattern of E. coli isolates was determined by simple disk diffusion method. The MuellerHinton agar (Merck, Germany) media were used for antibiotic susceptibility test. Principles of the Clinical and Laboratory Standards Institute (CLSI) were used for this purpose [19]. Susceptibility of E. coli isolates were tested against tetracycline (30 u/disk), ampicillin (10 u/disk), cefotaxime $(30 \mu \mathrm{g} /$ disk), gentamicin $(10 \mu \mathrm{g} /$ disk $)$, ciprofloxacin $(5 \mu \mathrm{g} /$ disk), amikacin (30 u/disk), ceftazidime (30 $\mu \mathrm{g} /$ disk), imipenem (30 u/disk), cotrimoxazole (30 $\mu \mathrm{g} /$ disk), enrofloxacin $(5 \mu \mathrm{g} /$ disk $)$, sulfamethoxazole $(25 \mu \mathrm{g} /$ disk $)$, trimethoprim (5 $\mu \mathrm{g} /$ disk), streptomycin $(10 \mu \mathrm{g} /$ disk) and chloramphenicol $(30 \mu \mathrm{g} /$ disk) antibiotic agents (Oxoid, UK). All of the inoculated plates were aerobically incubated at $37^{\circ} \mathrm{C}$ for $18-24 \mathrm{~h}$. Results were interpreted based on the instruction provided by CLSI [19]. E. coli ATCC 25922 was used as positive control.

\section{Statistical analysis}

Data obtained from all tests were transferred to the Microsoft Excel spreadsheet (Microsoft Corp., Redmond, WA) for analysis. At first, all data were subjected to Kolmogorov-Smirnov test to study their distribution. Then, the statistical analysis was performed using SPSS/20.0 software (SPSS Inc., Chicago, IL). $P$-values were calculated using Chi-square and Fisher's exact tests. Statistical analysis was used to find any significant relationship for prevalence of E. coli and also STEC strains between different samples, seasonal distribution of bacteria, distribution of $\mathrm{O}$-serogroups, virulence factors and antibiotic resistance. The $P$-value less than 0.05 was considered statistically significant.

\section{Results}

Table 2 represents the prevalence of $E$. coli strains in different types of milk samples and dairy products. One-hundred and eighty-one out of 600 samples (30.16\%) were positive for E. coli strains. Cheese $(80 \%)$ and raw buffalo milk (50\%) samples had the highest prevalence of
E. coli, while raw camel milk (6.66\%) had the lowest. There were no positive results for Kashk and dough samples. Statistical significant difference was seen between types of samples and prevalence of $E$. coli $(P<0.05)$.

Figure 1 revealed the seasonal prevalence of $E$. coli strains. Raw milk and traditional dairy product samples which were collected through the summer season had the highest prevalence of $E$. coli (62.50\%). Statistical significant difference was seen for the prevalence of $E$. coli strains between hot and cold seasons $(P=0.018)$.

Table 3 represents the prevalence of EHEC and AEEC subtypes in the E. coli strains isolated from raw milk and traditional dairy product samples. Prevalence of EHEC subtype in raw bovine, ovine, caprine and buffalo milk and traditional cheese, yoghurt, butter, cream and ice-cream samples was $25 \%, 22.22 \%, 27.27 \%, 35.71 \%, 32 \%, 33.33 \%$, $16.66 \%, 25 \%$ and $22.22 \%$, respectively. Prevalence of AEEC subtype in raw bovine, ovine, caprine and buffalo milk and traditional cheese, yoghurt, butter, cream and ice-cream samples was $31.25 \%, 33.33 \%, 36.36 \%, 35.71 \%$, $36 \%, 33.33 \%, 50 \%, 50 \%$ and $55.55 \%$, respectively. E. coli strains of the EHEC subtype were positive for all stx1, eae and ehly virulence genes. Statistical significant difference was seen between the prevalence of EHEC and AEEC subtypes $(P<0.01)$. Sixty-four out of $181 E$. coli isolates (35.35\%) were positive for AEEC and EHEC subtypes. These isolates were determined as STEC strains. There were no STEC strains in the raw camel milk samples. E. coli strains of the EHEC subtype were recognized as O157 serogroup.

Table 4 represents the prevalence of $\mathrm{O} 157$ and non-O157 serogroups in the STEC strains isolated from raw milk and traditional dairy product samples. O157 (43.75\%) and O26 (37.50\%) were the most commonly detected O-serogroups. Prevalence of O111, O45, O113 and O121 serogroups were $9.37 \%, 1.50 \%, 1.50 \%$ and $6.25 \%$, respectively. There were no positive results for O145, O91 and O128 serogroups. Statistical significant difference was seen between types of samples and prevalence of $\mathrm{O}$-serogroups $(P<0.05)$.

Table 5 shows the distribution of antibiotic resistance genes amongest the STEC strains isolated from raw milk and traditional dairy product samples. Aac(3)-IV (100\%), CITM (96.87\%) and tetA (76.56\%) were the most commonly detected antibiotic resistance genes. Prevalence of cmlA (1.50\%), cat1 (18.75\%) and tetB (20.31\%) antibiotic resistance genes were low. Statistical significant difference was seen between the types of samples and distribution of antibiotic resistance genes $(P<0.05)$.

Table 6 indicates the prevalence of antibiotic resistance in the STEC strains isolated from raw milk and traditional dairy product samples. STEC strains harbored the highest prevalence of resistance against ampicillin $(100 \%)$, gentamicin $(100 \%)$ and tetracycline $(96.87 \%)$ antibiotics. Statistical significant difference was seen between 
Table 1 Primers and PCR conditions used for characterization of virulence genes, O-serogroups and antibiotic resistance genes in the STEC strains isolated from raw milk and traditional dairy product samples

\begin{tabular}{|c|c|c|c|c|}
\hline Target gene & Primer sequence $\left(5^{\prime}-3^{\prime}\right)$ & PCR product (bp) & PCR programs & PCR Volume $(50 \mu \mathrm{L})$ \\
\hline 0157 & $\begin{array}{l}\text { F: CGGACATCCATGTGATATGG } \\
\text { R: TTGCCTATGTACAGCTAATCC }\end{array}$ & 259 & $\begin{array}{l}1 \text { cycle: } \\
95^{\circ 0}-1--1-1-3 \mathrm{~min}\end{array}$ & $\begin{array}{l}5 \mu \mathrm{LPCR} \text { buffer } 10 \mathrm{X} \\
2 \mathrm{mM} \mathrm{MgCl}_{2}\end{array}$ \\
\hline 0145 & $\begin{array}{l}\text { F: CCATCAACAGATTTAGGAGTG } \\
\text { R: TTCTACCGCGAATCTATC }\end{array}$ & 609 & \multirow{3}{*}{ 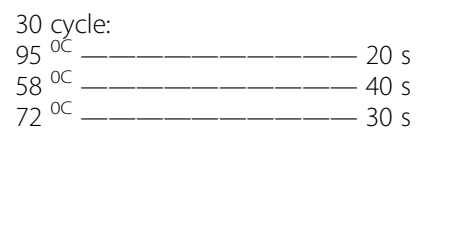 } & \multirow{3}{*}{$\begin{array}{l}150 \mu \mathrm{M} \text { dNTP (Fermentas) } \\
0.75 \mu \mathrm{M} \text { of each primers F \& R } \\
\text { 1.5 U Taq DNA polymerase } \\
\text { (Fermentas) }\end{array}$} \\
\hline 0103 & $\begin{array}{l}\text { F: TTGGAGCGTTAACTGGACCT } \\
\text { R: GCTCCCGAGCACGTATAAG }\end{array}$ & 321 & & \\
\hline $\mathrm{O} 26$ & $\begin{array}{l}\text { F: CAGAATGGTTATGCTACTGT } \\
\text { R: CTTACATITGTITTCGGCATC }\end{array}$ & 423 & & \\
\hline 0111 & $\begin{array}{l}\text { F: TAGAGAAATTATCAAGTTAGTTCC } \\
\text { R: ATAGTTATGAACATCTTGTTIAGC }\end{array}$ & 406 & $\begin{array}{l}1 \text { cycle: } \\
72^{\circ \mathrm{C}}-1-\_-1-1-8 \mathrm{~min}\end{array}$ & $3 \mu \mathrm{L}$ DNA template \\
\hline O91 & $\begin{array}{l}\text { F: GCTGACCTTCATGATCTGTTGA } \\
\text { R: TAATITAACCCGTAGAATCGCTGC }\end{array}$ & 291 & \multirow{5}{*}{ 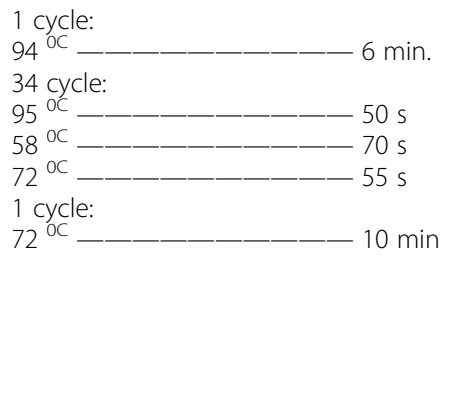 } & \multirow{5}{*}{$\begin{array}{l}5 \mu \mathrm{L} \text { PCR buffer } 10 \mathrm{X} \\
2 \mathrm{mM} \mathrm{MgCl} \\
150 \mu \mathrm{M} \text { dNTP (Fermentas) } \\
0.75 \mu \mathrm{M} \text { of each primers } \mathrm{F} \& \mathrm{R} \\
1.5 \cup \text { Taq DNA polymerase } \\
\text { (Fermentas) } \\
3 \mu \mathrm{L} \text { DNA template }\end{array}$} \\
\hline 0128 & $\begin{array}{l}\text { F: GCTTTCTGCCGATATTTGGC } \\
\text { R: CCGACGGACTGATGCCGGTGATT }\end{array}$ & 289 & & \\
\hline 0121 & $\begin{array}{l}\text { F: TGGCTAGTGGCATTCTGATG } \\
\text { R: TGATACTITAGCCGCCCTTG }\end{array}$ & 322 & & \\
\hline 0113 & $\begin{array}{l}\text { F: GGGTTAGATGGAGCGCTATTGAGA } \\
\text { R: AGGTCACCCTCTGAATTATGGCAG }\end{array}$ & 771 & & \\
\hline O45 & $\begin{array}{l}\text { F: CCGGGTTTCGATTTGTGAAGGTTG } \\
\text { R: CACAACAGCCACTACTAGGCAGAA }\end{array}$ & 527 & & \\
\hline stx 1 & $\begin{array}{l}\text { F: AAATCGCCATTCGTTGACTACTTCT } \\
\text { R: TGCCATTCTGGCAACTCGCGATGCA }\end{array}$ & 366 & \multirow{4}{*}{ 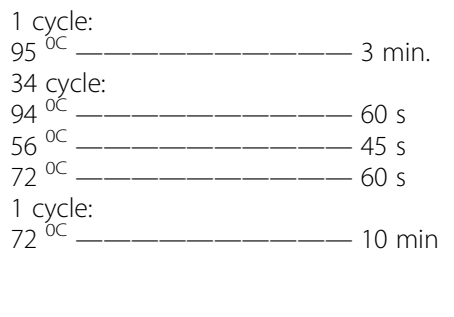 } & \multirow{4}{*}{$\begin{array}{l}5 \mu \mathrm{L} \text { PCR buffer } 10 \mathrm{X} \\
2 \mathrm{mM} \mathrm{MgCl} \\
150 \mu \mathrm{M} \text { dNTP (Fermentas) } \\
0.75 \mu \mathrm{M} \text { of each primers } \mathrm{F} \& \mathrm{R} \\
1.5 \cup \text { Taq DNA polymerase } \\
\text { (Fermentas) } \\
3 \mu \mathrm{L} \text { DNA template }\end{array}$} \\
\hline$s t \times 2$ & $\begin{array}{l}\text { F: CGATCGTCACTCACTGGTTCATCA } \\
\text { R: GGATATTCTCCCCACTCTGACACC }\end{array}$ & 282 & & \\
\hline eaeA & $\begin{array}{l}\text { F: TGCGGCACAACAGGCGGCGA } \\
\text { R: CGGTCGCCGCACCAGGATTC }\end{array}$ & 629 & & \\
\hline ehly & $\begin{array}{l}\text { F: CAATGCAGATGCAGATACCG } \\
\text { R: CAGAGATGTCGTTGCAGCAG }\end{array}$ & 432 & & \\
\hline $\operatorname{aadAl}$ & $\begin{array}{l}\text { F: TATCCAGCTAAGCGCGAACT } \\
\text { R: ATTTGCCGACTACCTTGGTC }\end{array}$ & 447 & \multirow{11}{*}{ 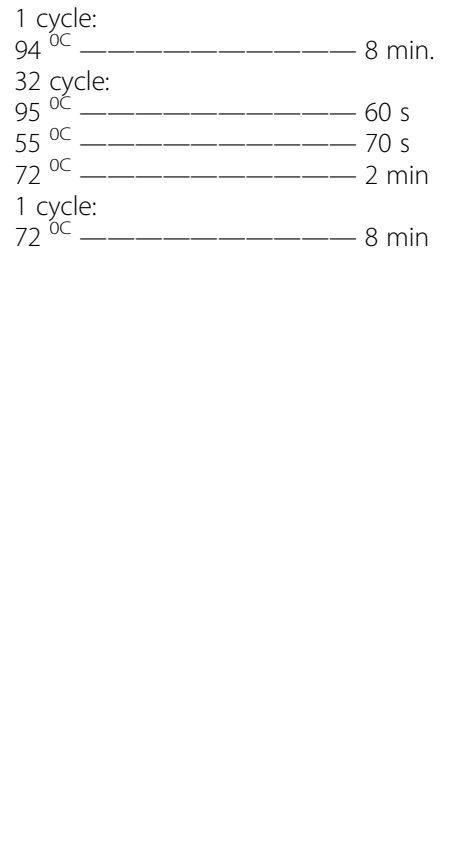 } & \multirow{11}{*}{$\begin{array}{l}5 \mu \mathrm{L} \text { PCR buffer } 10 \mathrm{X} \\
2 \mathrm{mM} \mathrm{MgCl} \\
150 \mu \mathrm{M} \text { dNTP (Fermentas) } \\
0.75 \mu \mathrm{M} \text { of each primers } \mathrm{F} \& \mathrm{R} \\
1.5 \cup \text { Taq DNA polymerase } \\
\text { (Fermentas) } \\
3 \mu \mathrm{L} \text { DNA template }\end{array}$} \\
\hline tetA & $\begin{array}{l}\text { F: GGTTCACTCGAACGACGTCA } \\
\text { R: CTGTCCGACAAGTTGCATGA }\end{array}$ & 577 & & \\
\hline tetB & $\begin{array}{l}\text { F: CCTCAGCTTCTCAACGCGTG } \\
\text { R: GCACCTTGCTGATGACTCTT }\end{array}$ & 634 & & \\
\hline dfrAl & $\begin{array}{l}\text { F: GGAGTGCCAAAGGTGAACAGC } \\
\text { R: GAGGCGAAGTCTTGGGTAAAAAC }\end{array}$ & 367 & & \\
\hline$a n r$ & $\begin{array}{l}\text { F: GGGTATGGATATTATTGATAAAG } \\
\text { R: CTAATCCGGCAGCACTATTTA }\end{array}$ & 670 & & \\
\hline $\operatorname{aac}(3)-I V$ & $\begin{array}{l}\text { F: CTTCAGGATGGCAAGTTGGT } \\
\text { R: TCATCTCGTTCTCCGCTCAT }\end{array}$ & 286 & & \\
\hline sult & $\begin{array}{l}\text { F: TTCGGCATTCTGAATCTCAC } \\
\text { R: ATGATCTAACCCTCGGTCTC }\end{array}$ & 822 & & \\
\hline blaSHV & $\begin{array}{l}\text { F: TCGCCTGTGTATTATCTCCC } \\
\text { R: CGCAGATAAATCACCACAATG }\end{array}$ & 768 & & \\
\hline CITM & $\begin{array}{l}\text { F: TGGCCAGAACTGACAGGCAAA } \\
\text { R: TTCTCCTGAACGTGGCTGGC }\end{array}$ & 462 & & \\
\hline cat1 & $\begin{array}{l}\text { F: AGTTGCTCAATGTACCTATAACC } \\
\text { R: TTGTAATTCATTAAGCATTCTGCC }\end{array}$ & 547 & & \\
\hline $\mathrm{cm} / \mathrm{A}$ & $\begin{array}{l}\text { F: CCGCCACGGTGTTGTTGTTATC } \\
\text { R: CACCTTGCCTGCCCATCATTAG }\end{array}$ & 698 & & \\
\hline
\end{tabular}


Table 2 Prevalence of Escherichia coli strains isolated from raw milk and traditional dairy product samples

\begin{tabular}{lll}
\hline Types of samples & No. samples collected & No positive strains (\%) \\
\hline Raw bovine milk & 70 & $30(42.85)$ \\
Raw ovine milk & 60 & $21(35)$ \\
Raw caprine milk & 60 & $23(38.33)$ \\
Raw buffalo milk & 40 & $20(50)$ \\
Raw camel milk & 30 & $2(6.66)$ \\
Cheese & 50 & $40(80)$ \\
Yoghurt & 60 & $5(8.33)$ \\
Kashk & 50 & - \\
Dough & 50 & - \\
Butter & 40 & $10(25)$ \\
Cream & 40 & $15(37.50)$ \\
Ice-cream & 50 & $15(30)$ \\
Total & 600 & $181(30.16)$ \\
\hline
\end{tabular}

the types of samples and prevalence of antibiotic resistance $(P<0.05)$.

Figure 2 shows the prevalence of multi-drug resistant STEC strains isolated from raw milk and traditional dairy product samples. All of the STEC strains were resistant to at least an antibiotic, while prevalence of resistance against more than 7 antibiotics was $43.75 \%$.

\section{Discussion}

As far as we know, the current research is the most comprehensive report of the molecular characterization and study the phenotypic and genotypic properties of antibiotic resistance of the STEC strains isolated from raw milk and traditional dairy product samples. We found that $30.16 \%$ of raw milk and traditional dairy product samples were contaminated with $E$. coli strains. We also found that the prevalence of STEC strains were $35.35 \%$ (64/181). Ombarak et al. (2016) [20] reported

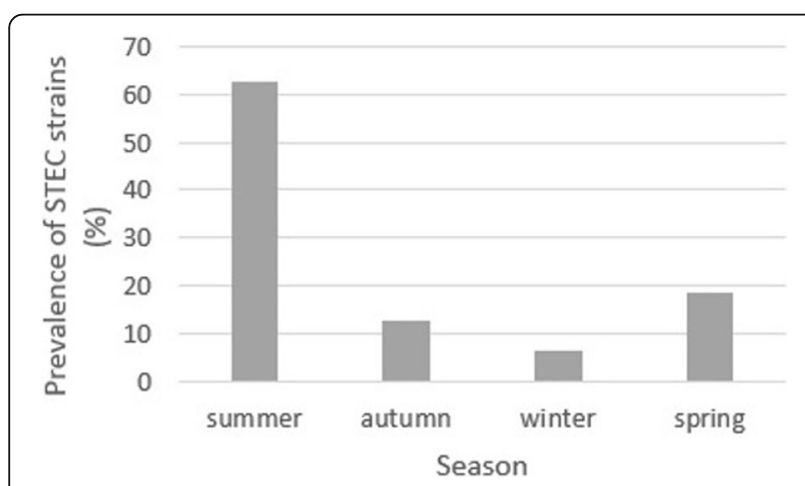

Fig. 1 Seasonal prevalence of Escherichia coli strains in raw milk and traditional dairy product samples that the prevalence of $E$. coli strains in various types of dairy products had a range of 21 to $77 \%$. Elhadidy and Mohammed (2012) [21] revealed that $11.29 \%$ of cheese samples were contaminated with the STEC strains which was lower than our findings (34\%). Total prevalence of E. coli strains in raw milk and traditional dairy product samples of studies conducted on Switzerland [22], Iran [23], Italy [24], Egypt [25], Turkey [26], China [27], and Spain [28] had range between $1 \%$ to $27 \%$ which were lower than our reported prevalence rate.

There were some probable explanations for the high prevalence of E. coli and also STEC strains in raw milk and traditional dairy product samples of our study [5, 7, 29]. At first. Iranian ranchers used from their hand and also traditional equipment for milking procedure which increase the risk of transmission of bacteria into the milk and dairy products $[5,7,29]$. At second, lack of maintenance of raw milk samples at temperatures below than $4{ }^{\circ} \mathrm{C}$ which facilitates survival and proliferation of bacteria $[5,7,29]$. At third, using from unpasteurized milk for production of dairy products which facilitates the survival of bacteria in dairy products. $[5,7,29]$. Transmission of pathogenic agents from the infected staffs of the milking halls and also factories is another important risk factor. There were no positive results for kashk and dough samples. Production of these two dairy products need high thermal processing which caused to destruction of pathogenic agents.

We found marked seasonality in the distribution of $E$. coli strains in raw milk and traditional dairy product samples. High prevalence of $E$. coli strains in summer season $(64.10 \%)$ could be related to the low levels of individual hygiene in this season. The higher prevalence of STEC strains may be due to the higher activity of bacteria in hot seasons. Of studies which have been conducted in this field [29-31], all have shown a seasonal distribution for $E$. coli strains with a higher prevalence of bacteria in warmer seasons [32-34].

Results of the current research revealed that raw milk and traditional dairy product samples harbored the high prevalence of virulent STEC strains. We found that STEC strains harbored the high prevalence of $s t x 1$, stx2, eaeA and ehlyA virulence factors. Some isolates were positive for multiple virulence genes which represented their high pathogenicity. Momtaz et al. [5] revealed that stx1, papA, cnf1, traT, cnf2, eaeA and ehly were the most commonly detected virulence factors amongst the STEC strains of dairy products. Dehkordi et al. [7] reported that the prevalence of stx1, stx2, eaeA and ehly genes amongst the STEC strains of fermented dairy products were $44 \%, 30 \%, 36 \%$ and $28 \%$, respectively. We found that AEEC subtypes had the higher prevalence than EHEC subtype. This finding had also been reported by other researchers $[5-7,17,18,28,29]$. All of the previously 
Table 3 Prevalence of pathogenic subtypes and related virulence factors in Escherichia coli strains isolated from raw milk and traditional dairy product samples

\begin{tabular}{|c|c|c|c|c|c|c|c|}
\hline $\begin{array}{l}\text { Samples } \\
\text { (No. positive) }\end{array}$ & Subtypes & $\begin{array}{l}\text { No. positive } \\
\text { samples }\end{array}$ & Virulence genes & $\begin{array}{l}\text { Samples } \\
\text { (No. positive) }\end{array}$ & Subtypes & $\begin{array}{l}\text { No. positive } \\
\text { samples }\end{array}$ & Virulence genes \\
\hline \multirow{4}{*}{$\begin{array}{l}\text { Raw bovine } \\
\text { milk (30) }\end{array}$} & Non detected & $7(43.75)$ & - & Yoghurt (5) & Non detected & $1(33.33)$ & - \\
\hline & EHEC & $4(25)$ & stx1, eae, ehly: 4 (100) & & EHEC & $1(33.33)$ & stx1, eae, ehly: 1 (100) \\
\hline & AEEC & $5(31.25)$ & $\begin{array}{l}\text { stx1: } 5(100) \\
\text { stx2: } 3(60) \\
\text { eaeA: } 5(100) \\
\text { stx1, eaeA: } 3(60) \\
\text { stx2, eaeA: } 2(40) \\
\text { stx1, stx2, eaeA: } 1 \text { (20) }\end{array}$ & & AEEC & $1(33.33)$ & $\begin{array}{l}\text { stx1: } 1(100) \\
\text { stx2: } 1(100) \\
\text { eaeA: } 1(100) \\
\text { stx1, eaeA: } 1(100) \\
\text { stx2, eaeA: } 1(100) \\
\text { stx1, stx2, eaeA: } 1 \text { (100) }\end{array}$ \\
\hline & Total & $16(53.33)$ & & & Total & $3(60)$ & \\
\hline \multirow{4}{*}{$\begin{array}{l}\text { Raw ovine } \\
\text { milk (21) }\end{array}$} & Non detected & $4(44.44)$ & - & Butter (10) & Non detected & $2(33.33)$ & - \\
\hline & EHEC & $2(22.22)$ & stx1, eae, ehly: 2 (100) & & EHEC & $1(16.66)$ & stx1, eae, ehly: 1 (100) \\
\hline & AEEC & $3(33.33)$ & $\begin{array}{l}\text { stx1: } 3(100) \\
\text { stx2: } 1(33.33) \\
\text { eaeA: } 3(100) \\
\text { stx1, eaeA: } 1 \text { (33.33) } \\
\text { stx2, eaeA: } 1 \text { (33.33) } \\
\text { stx1, stx2, eaeA: } 1 \text { (33.33) }\end{array}$ & & AEEC & $3(50)$ & $\begin{array}{l}\text { stx1: } 3(100) \\
\text { stx2: } 1(33.33) \\
\text { eaeA: } 3(100) \\
\text { stx1, eaeA: } 1 \text { (33.33) } \\
\text { stx2, eaeA: } 1 \text { (33.33) } \\
\text { stx1, stx2, eaeA: } 1 \text { (33.33) }\end{array}$ \\
\hline & Total & $9(42.85)$ & & & Total & $6(60)$ & \\
\hline \multirow{4}{*}{$\begin{array}{l}\text { Raw caprine } \\
\text { milk (23) }\end{array}$} & Non detected & $4(36.36)$ & - & Cream (15) & Non detected & $2(25)$ & - \\
\hline & EHEC & $3(27.27)$ & stx1, eae, ehly: 2 (100) & & EHEC & $2(25)$ & stx1, eae, ehly: 2 (100) \\
\hline & AEEC & $4(36.36)$ & $\begin{array}{l}\text { stx1: } 4(100) \\
\text { stx2: } 2(50) \\
\text { eaeA: } 4(100) \\
\text { stx1, eaeA: } 2(50) \\
\text { stx2, eaeA: } 1(25) \\
\text { stx1, stx2, eaeA: } 1 \text { (25) }\end{array}$ & & AEEC & $4(50)$ & $\begin{array}{l}\text { stx1: } 4(100) \\
\text { stx2: } 2(50) \\
\text { eaeA: } 3(75) \\
\text { stx1, eaeA: } 2(50) \\
\text { stx2, eaeA: } 1(25) \\
\text { stx1, stx2, eaeA: } 1 \text { (25) }\end{array}$ \\
\hline & Total & $11(47.82)$ & & & Total & $8(53.33)$ & \\
\hline \multirow{4}{*}{$\begin{array}{l}\text { Raw buffalo } \\
\text { milk (20) }\end{array}$} & Non detected & $4(28.57)$ & - & Ice-cream (15) & Non detected & $2(22.22)$ & - \\
\hline & EHEC & $5(35.71)$ & stx1, eae, ehly: 5 (100) & & EHEC & $2(22.22)$ & stx1, eae, ehly: 2 (100) \\
\hline & AEEC & $5(35.71)$ & $\begin{array}{l}\text { stx1: } 5(100) \\
\text { stx2: } 3(60) \\
\text { eaeA: } 5(100) \\
\text { stx1, eaeA: } 3(60) \\
\text { stx2, eaeA: } 1(20) \\
\text { stx1, stx2, eaeA: } 1 \text { (20) }\end{array}$ & & AEEC & $5(55.55)$ & $\begin{array}{l}\text { stx1: } 5(100) \\
\text { stx2: } 3(60) \\
\text { eaeA: } 5(100) \\
\text { stx1, eaeA: } 2(40) \\
\text { stx2, eaeA: } 2(40) \\
\text { stx1, stx2, eaeA: } 1 \text { (20) }\end{array}$ \\
\hline & Total & $14(70)$ & & & Total & $9(60)$ & \\
\hline
\end{tabular}

Raw came

milk (2)

$\begin{array}{lll} & \text { AEEC } & - \\ & & \\ & & \\ \text { Cheese (40) } & \text { Total } & 1(50) \\ & \text { Non detected } & 8(32) \\ & \text { EHEC } & 8(32) \\ & \text { AEEC } & 9(36)\end{array}$

Total

$25(62.50)$
Table 3 Prevalence of pathogenic subtypes and related virulence factors in Escherichia coli strains isolated from raw milk and traditional dairy product samples (Continued)

published articles in this field [5-7, 17, 18, 28, 29] found that EHEC strains harbored all stx1, eae and ehly genes together which was similar to our findings. Simultaneous presence of stx 1 and eaeA and also stx 1 and ehly virulence factors in the STEC strains is another important finding of the present study which was supported by previous researches [5-7, 17, 18, 28, 29].

We found that both O157 and non-O157 (especially O26, O111 and O121) serogroups had a considerable prevalence in STEC strains isolated from raw milk and traditional dairy product samples. These serogroups were also predominant in the STEC strains isolated from ground beef (Argentina) [30], hospital foods (Iran) [31], dairy products (France) [32] and milk (Spain) [33]. 
Table 4 Prevalence of O-serogroups in the STEC strains isolated from raw milk and traditional dairy product samples

\begin{tabular}{|c|c|c|c|c|c|c|c|c|c|c|}
\hline \multirow[t]{2}{*}{ Samples (No. STEC strains) } & \multicolumn{10}{|c|}{ Distribution of O-serogroups (\%) } \\
\hline & 0157 & $\mathrm{O} 26$ & 0103 & 0111 & 0145 & $\mathrm{O} 45$ & O91 & 0113 & 0121 & 0128 \\
\hline Raw bovine milk (9) & $4(44.44)$ & $3(33.33)$ & - & $1(11.11)$ & - & - & - & - & $1(11.11)$ & - \\
\hline Raw ovine milk (5) & $2(40)$ & $2(40)$ & - & $1(20)$ & - & - & - & - & - & - \\
\hline Raw caprine milk (7) & $3(42.85)$ & $2(28.57)$ & - & - & - & $1(14.28)$ & - & - & $1(14.28)$ & - \\
\hline Raw buffalo milk (10) & $5(50)$ & $4(40)$ & - & $1(10)$ & - & - & - & - & - & - \\
\hline Cheese (17) & $8(47.05)$ & $6(35.29)$ & - & $1(5.88)$ & - & - & - & $1(5.88)$ & $1(5.88)$ & - \\
\hline Yoghurt (2) & $1(50)$ & $1(50)$ & - & - & - & - & - & - & - & - \\
\hline Butter (4) & $1(25)$ & $2(50)$ & - & $1(25)$ & - & - & - & - & - & - \\
\hline Cream (6) & $2(33.33)$ & $2(33.33)$ & - & $1(16.66)$ & - & - & - & - & $1(16.66)$ & - \\
\hline Ice-cream (4) & $2(50)$ & $2(50)$ & - & - & - & - & - & - & - & - \\
\hline Total (64) & $28(43.75)$ & $24(37.50)$ & - & $6(9.37)$ & - & $1(1.56)$ & - & $1(1.56)$ & $4(6.25)$ & - \\
\hline
\end{tabular}

Hemmatinezhad et al. (2015) [34] reported that the prevalence of $\mathrm{O} 103, \mathrm{O} 121$ and $\mathrm{O} 128$ serogroups in STEC strains isolated from poultry meat samples were $3.84 \%, 11.53 \%$ and $5.76 \%$, respectively. Their findings revealed that $\mathrm{O} 26(30.76 \%)$ and $\mathrm{O} 157$ (25.96\%) were the most commonly detected O-serogroups. High prevalence of O157 serogroup in the STEC strains of our research and also those of other investigations showed that collected samples were contaminated with animal sources and especially feces. Previous studies which were conducted in Turkey [35], Canada [36] and Africa [37] had similar conclusions.

Majority of the STEC strains of our research harbored the high prevalence of resistance against commonly used antibiotics. We found that phenotypic resistance pattern of STEC strains was supported by the genotypic resistance pattern. In the other hand, high prevalence of resistance of STEC strains isolated from raw milk and traditional dairy product samples was accompanied with high prevalence of antibiotic resistance genes. Multi-drug resistance was also seen for some of the STEC strains isolated from raw milk and traditional dairy product samples. Illegal and inaccurate prescription of antibiotics especially in veterinary medicine is may be the main reason for the high prevalence of antibiotic resistance in the STEC strains isolated from raw milk and traditional dairy product samples. Dehkordi et al. (2014) [7] revealed that the STEC strains isolated from fermented dairy products showed a high prevalence of resistance against tetracycline (84\%), penicillin (46\%), cephalothin (42\%), ampicillin (38\%) and streptomycin (36\%). They showed that high prevalence of resistance against commonly used antibiotics was also accompanied with high prevalence of the genes that encode resistance to tetracycline $(\operatorname{tet} A(76 \%)$ and tetB (70\%)), cephalothin (blaSHV (38\%)), ampicillin (CITM $(36 \%)$ ) and gentamicin (acc(3)-IV (32\%)). Previous study [31] showed that the prevalence of aac(3)-IV, CITM, tetA, dfrA1 and sul1 antibiotic resistance genes amongst the STEC strains isolated from food samples were $100 \%$, $100 \%, 62.50 \%, 56.25 \%$ and $56.25 \%$, respectively. Tark et al.

Table 5 Prevalence of antibiotic resistance genes in the STEC strains isolated from raw milk and traditional dairy product samples

\begin{tabular}{llllllllllll}
\hline \multirow{2}{*}{$\begin{array}{l}\text { Samples } \\
\text { No. STEC strains) }\end{array}$} & \multicolumn{1}{l}{ Distribution of antibiotic resistance genes (\%) } \\
\cline { 2 - 6 } & aadA1 & tetA & tetB & dfrA1 & anr & aac(3)-IV & sul1 & blaSHV & CITM & cat1 & cmIA \\
\hline Raw bovine milk (9) & $3(33.33)$ & $7(77.77)$ & $1(11.11)$ & $5(55.55)$ & $1(11.11)$ & $9(100)$ & $4(44.44)$ & $3(33.33)$ & $9(100)$ & $1(11.11)$ & - \\
Raw ovine milk (5) & $3(60)$ & $4(80)$ & $1(20)$ & $3(60)$ & $1(20)$ & $5(100)$ & $2(40)$ & $1(20)$ & $5(100)$ & $1(20)$ & - \\
Raw caprine milk (7) & $4(57.14)$ & $5(71.42)$ & $2(28.57)$ & $4(57.14)$ & $2(28.57)$ & $7(100)$ & $2(28.57)$ & $2(28.57)$ & $7(100)$ & $1(14.28)$ & - \\
Raw buffalo milk (10) & $3(30)$ & $8(80)$ & $2(20)$ & $6(60)$ & $3(30)$ & $10(100)$ & $5(50)$ & $3(30)$ & $9(90)$ & $2(20)$ & - \\
Cheese (17) & $7(41.17)$ & $12(70.58)$ & $4(23.52)$ & $8(47.05)$ & $4(23.52)$ & $17(100)$ & $7(41.17)$ & $5(29.41)$ & $16(94.11)$ & $4(23.52)$ & $1(755.88$ \\
Yoghurt (2) & $1(50)$ & $2(100)$ & - & $1(50)$ & - & $2(100)$ & $1(50)$ & $1(50)$ & $2(100)$ & - & - \\
Butter (4) & $3(75)$ & $3(75)$ & $1(25)$ & $2(50)$ & $1(25)$ & $4(100)$ & $2(50)$ & $1(25)$ & $4(100)$ & $1(25)$ & - \\
Cream (6) & $4(66.66)$ & $5(83.33)$ & $1(16.66)$ & $3(50)$ & $1(16.66)$ & $6(100)$ & $2(33.33)$ & $2(33.33)$ & $6(100)$ & $1(16.66)$ & - \\
Ice-cream (4) & $3(75)$ & $3(75)$ & $1(25)$ & $3(75)$ & $1(25)$ & $4(100)$ & $2(50)$ & $2(50)$ & $4(100)$ & $1(25)$ & - \\
Total (64) & $31(48.43)$ & $49(76.56)$ & $13(20.31)$ & $35(54.68)$ & $14(21.87)$ & $64(100)$ & $27(42.18)$ & $20(31.25)$ & $62(96.87)$ & $12(18.75)$ & $1(1.56)$ \\
\hline
\end{tabular}


Table 6 Pattern of antibiotic resistance for STEC strains isolated from raw milk and traditional dairy product samples

\begin{tabular}{|c|c|c|c|c|c|c|c|c|c|c|}
\hline \multirow{2}{*}{$\begin{array}{l}\text { Antibiotic } \\
\text { resistance }\end{array}$} & \multicolumn{6}{|c|}{ Samples (No. STEC strains) } & \multirow[b]{2}{*}{ Butter (4) } & \multirow[b]{2}{*}{ Cream (6) } & \multirow[b]{2}{*}{ Ice-cream (4) } & \multirow[b]{2}{*}{ Total (64) } \\
\hline & $\begin{array}{l}\text { Raw bovine } \\
\text { milk (9) }\end{array}$ & $\begin{array}{l}\text { Raw ovine } \\
\text { milk (5) }\end{array}$ & $\begin{array}{l}\text { Raw caprine } \\
\text { milk (7) }\end{array}$ & $\begin{array}{l}\text { Raw buffalo } \\
\text { milk (10) }\end{array}$ & Cheese (17) & Yoghurt (2) & & & & \\
\hline Tetracycline & $9(100)$ & $5(100)$ & $7(100)$ & $9(90)$ & $16(94.11)$ & $2(100)$ & $4(100)$ & $6(100)$ & $4(100)$ & $62(96.87)$ \\
\hline Ampicillin & $9(100)$ & $5(100)$ & $7(100)$ & $10(100)$ & $17(100)$ & $2(100)$ & $4(100)$ & $6(100)$ & $4(100)$ & $64(100)$ \\
\hline Gentamicin & $9(100)$ & $5(100)$ & $7(100)$ & $10(100)$ & $17(100)$ & $2(100)$ & $4(100)$ & $6(100)$ & $4(100)$ & $64(100)$ \\
\hline Amikacin & $6(66.66)$ & $3(60)$ & $5(71.42)$ & $5(50)$ & $12(70.58)$ & $1(50)$ & $3(75)$ & $3(50)$ & $2(50)$ & $40(62.50)$ \\
\hline Imipenem & $1(11.11)$ & - & - & $1(10)$ & $2(11.76)$ & - & - & - & - & $4(6.25)$ \\
\hline Sulfamethoxazole & $5(55.55)$ & $3(60)$ & $2(28.57)$ & $5(50)$ & $7(41.17)$ & $1(50)$ & $2(50)$ & $3(50)$ & $2(50)$ & $30(46.87)$ \\
\hline Cefotaxime & $4(44.44)$ & $2(40)$ & $1(14.28)$ & $3(30)$ & $3(41.17)$ & - & $1(25)$ & $1(16.66)$ & $1(25)$ & $16(25)$ \\
\hline Ciprofloxacin & $5(55.55)$ & $3(60)$ & $4(57.14)$ & $4(40)$ & $12(70.58)$ & $1(50)$ & $3(75)$ & $3(50)$ & $2(50)$ & $37(57.81)$ \\
\hline Enrofloxacin & $5(55.55)$ & $3(60)$ & $5(42.85)$ & $4(40)$ & $13(76.47)$ & $1(50)$ & $3(75)$ & $3(50)$ & $3(75)$ & $40(62.50)$ \\
\hline Cotrimoxazole & $4(44.44)$ & $3(60)$ & $2(28.57)$ & $3(30)$ & $6(35.29)$ & - & $2(50)$ & $2(33.33)$ & $2(50)$ & $24(37.50)$ \\
\hline Ceftazidime & $4(44.44)$ & $2(40)$ & $1(14.28)$ & $3(30)$ & $4(23.52)$ & - & $2(50)$ & $2(33.33)$ & $1(25)$ & $19(29.68)$ \\
\hline Trimethoprim & $4(44.44)$ & $3(60)$ & $2(28.57)$ & $5(50)$ & $8(47.05)$ & $1(50)$ & $2(50)$ & $3(50)$ & $2(50)$ & $30(46.87)$ \\
\hline Streptomycin & $4(44.44)$ & $3(60)$ & $4(57.14)$ & $4(40)$ & $8(47.05)$ & - & $2(50)$ & $2(33.33)$ & $1(25)$ & $29(45.31)$ \\
\hline Chloramphenicol & $2(22.22)$ & $1(20)$ & - & $2(20)$ & - & - & - & $1(16.66)$ & $1(25)$ & $3(4.68)$ \\
\hline
\end{tabular}

(2017) [38] determined that E. coli strains isolated from raw milk samples harbored the high prevalence of resistance against tetracycline (23.3\%), streptomycin (17.10\%), ampicillin (16.60\%), neomycin (11.80\%), and trimethoprim/sulfamethoxazole (11.20\%). Fifteen percent of their isolates had resistance against more than three classes of antibiotics. Study in Ethiopia [39] showed that STEC strains isolated from raw milk samples harbored the highest prevalence of resistance against streptomycin (81.80\%), trimethoprim-sulfamethoxazole (27.30\%), cefoxitin (54. $50 \%)$, kanamycin $(63.60 \%)$, gentamicin $(36.40 \%)$, tetracycline $(81.80 \%)$ and norfloxacin $(51.50 \%)$ which was similar to our findings. An Italian investigation [22] reported that STEC strains isolated from dairy products exhibited the highest levels of resistance against ampicillin, gentamicin, tetracycline, sulfamethoxazole and ciprofloxacin antibiotics.
The most significant finding obtained from our study and also those of other researches were the high prevalence of resistance against human-based antibiotics such as amikacin, imipenem, cefotaxime, ciprofloxacin, cotrimoxazole and ceftazidime. This finding showed that STEC strains isolated from raw milk and traditional dairy product samples may be transferred from infected humans. Therefore, some of the STEC strains of our study may be had anthropogenic origin and derived from infected staffs of the milking halls and also dairy producing factories. This finding was also supported by previous studies [5-7, 29, 31, 34].

We also found a considerable prevalence of resistance of STEC strains against chloramphenicol (4.68\%). However, chloramphenicol was listed as a forbidden antibiotic, but its highly irregular and excessive prescription may be cause its high prevalence of resistance. High prevalence of resistance against chloramphenicol was also reported by other

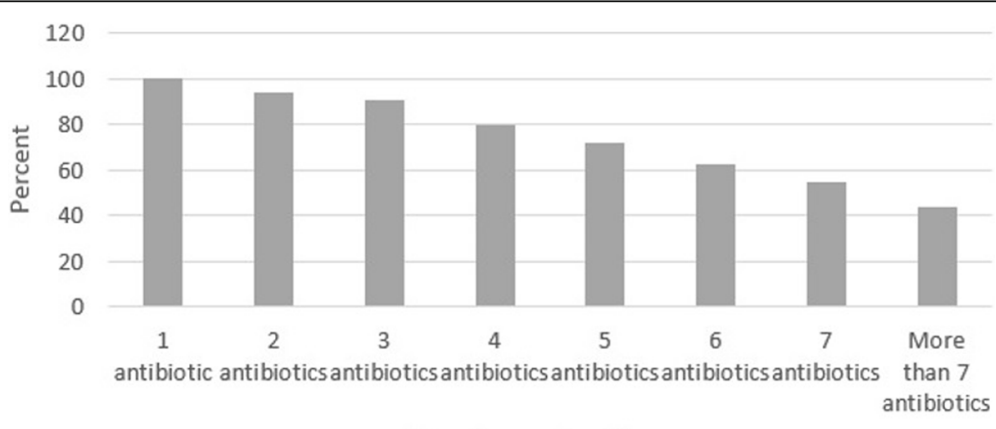

Prevalence of resistance

Fig. 2 Prevalence of multi-drug resistant STEC bacteria isolated from raw milk and traditional dairy product samples 
studies $[5-7,17,18,29,31,40]$. Findings of other investigations revealed that the STEC strains isolated from food samples harbored the high prevalence of resistance against chloramphenicol (1 to 50\%) [5-7, 17, 18, 29, 31, 40]. Differences in the prevalence of resistance against various types of antibiotics observed in our study and also other researches are may be due to the differences in the availability of antibiotics, their costs and finally idea of veterinarian for antibiotic prescription in various parts of the world.

High presence of virulent and resistant E. coli and also other foodborne pathogens have been reported from different types of food samples [41-58]. Findings of these researchers and also those of our investigation showed that pathogenic bacteria such as E. coli are not limited to health-care centers. In the other hand, community and especially foods may play an important role in transmission of pathogenic bacteria such as E. coli to humans. Furthermore, they are mainly act as reservoir of pathogenic bacteria such as E. coli in the community. Raw milk and traditional dairy product samples are not exception from this important regulation. Therefore, further studies are needed to determine the role of different types of food samples as risk factor for survival and transmission of pathogenic bacteria such as $E$. coli in the community. In addition to food, presence of $E$. coli strains have been reported previously from different types of clinical infections [59-74].

\section{Conclusions}

In conclusions, we recognized a considerable prevalence of $\mathrm{O} 26$ and $\mathrm{O} 157$ serogroups, stx 1 and eaeA virulence factors, resistance against ampicillin, gentamicin and tetracycline and aac(3)-IV, CITM and tet $A$ antibiotic resistance genes in the STEC strains isolated from raw milk and traditional dairy products. These characters besides the high prevalence of multi-drug resistant STEC strains represented an important public health issue regarding the consumption of raw milk and traditional dairy products. High prevalence of O157 serogroup which was accompanied with simultaneous presence of two or more putative virulence factors together showed their high pathogenicity. We found that kashk and dough were safe from contamination with $E$. coli strains. In addition, the prevalence of $E$. coli strains in raw camel milk samples was only 6.6\%. Presence of O157 serogroups, EHEC strains, human-based antibiotics and even antibiotic resistance genes which encode resistance against humanbased antibiotics in dairy products showed insufficiency of cooking time and temperature and transmission of pathogenic bacteria from infected staffs into the dairy samples. It seems that there were no strict supervisions on the principles of food hygiene in Iranian factories. Due to the low prevalence of STEC resistance against imipenem antibiotic, occurrence of food poisonings due to the STEC strains in tested samples can be treated with its regular prescription. Attentions to the principles of Hazard Analysis and Critical Control Point (HACCP) system can reduce the risk of STEC strains in raw milk and traditional dairy products. Complete boiling of raw milk before consumption and using from pasteurized dairy products were recommended to decrease the transmission of STEC strains to human. Attentions to the results of disk diffusion and principles of antibiotic prescription can decrease the risk of resistant STEC strains in raw milk and traditional dairy products.

\section{Abbreviations \\ AEEC: Attaching and effacing E. coli; E. coli: Escherichia coli; Eae: Intimin; EHEC: Enterohemolysin or Enterohaemorrhagic Escherichia coli; \\ Ehly: Hemolysin; HC: Hemorrhagic colitis; HUS: Hemolytic Uremic Syndrome; PCR: Polymerase Chain Reaction; SPSS: Statistical Package for the Social Sciences; STEC: Shiga toxin producing Escherichia coli;; Stx: Shiga toxin}

\section{Acknowledgements}

The authors would like to thank from the Islamic Azad University of Shahrekord, Shahrekord Iran for its important technical support.

\section{Availability of data and material}

All data generated or analyzed throughout this research are included in this published article.

\section{Funding}

This work was supported by the Molecular Biology Research Center, Baqiyatallah University of Medical Sciences, Tehran, Iran (Grant No. 96/114).

\section{Authors' contributions}

RR and FSD carried out the culture-based identification of bacteria and PCR genetic alignment. MSS and ER carried out the samples collection, disk diffusion, statistical analysis, writing and drafting of manuscript. All authors road and approved the final manuscript.

\section{Ethics approval and consent to participate}

The study was approved by the Ethical Committee of Research of the Molecular Biology Research Center, Baqiyatallah University of Medical Sciences, Tehran, Iran (Consent Ref Number 96-114). Verification of this research project and the licenses related to sampling process were approved by Prof. Reza Ranjbar and Prof. Ebrahim Rahimi (Approval Ref Number FST-96-114).

\section{Consent for publication}

There was no consent for publication.

\section{Competing interests}

The authors declare that they have no competing interests.

\section{Publisher's Note}

Springer Nature remains neutral with regard to jurisdictional claims in published maps and institutional affiliations.

\section{Author details}

${ }^{1}$ Molecular Biology Research Center, Systems Biology and Poisonings Institute, Baqiyatallah University of Medical Sciences, Tehran, Iran. ${ }^{2}$ Young Researchers and Elites Club, Shahrekord Branch, Islamic Azad University, Shahrekord, Iran. ${ }^{3}$ Doctor Veterinary Medicine, Faculty of Veterinary Medicine, Shahrekord Branch, Islamic Azad University, Shahrekord, Iran. ${ }^{4}$ Department of Food Hygiene and Public health, Faculty of Veterinary Medicine, Shahrekord Branch, Shahrekord, Iran. ${ }^{5}$ Department of Food Hygiene and Quality Control, Faculty of Veterinary Medicine, Shahrekord Branch, Islamic Azad University, Shahrekord, Iran. 


\section{Received: 31 October 2017 Accepted: 5 April 2018 Published online: 16 April 2018}

\section{References}

1. Rozenberg $S$, Body J-J, Bruyère $O$, Bergmann $P$, Brandi $M L$, Cooper $C$, Devogelaer J-P, Gielen E, Goemaere S, Kaufman J-M. Effects of dairy products consumption on health: benefits and beliefs - a commentary from the Belgian bone Club and the European Society for Clinical and Economic Aspects of osteoporosis, osteoarthritis and musculoskeletal diseases. Calcif Tissue Int. 2016;98:1-17.

2. Dehkordi FS, Haghighi Borujeni MR, Rahimi E, Abdizadeh R. Detection of Toxoplasma gondii in raw caprine, ovine, buffalo, bovine, and camel milk using cell cultivation, cat bioassay, capture ELISA, and PCR methods in Iran. Foodborne Pathog Dis. 2013;10:120-5.

3. Mousavi S, Dehkordi FS, Rahimi E. Virulence factors and antibiotic resistance of Helicobacter pylori isolated from raw milk and unpasteurized dairy products in Iran. J Venom Anim Toxins Incl Trop Dis. 2014;20:51.

4. Noori A, Keshavarzian F, Mahmoudi S, Yousefi M, Nateghi L. Comparison of traditional Doogh (yogurt drinking) and Kashk characteristics (two traditional Iranian dairy products). European Journal of Experimental Biology. 2013;3:252-5.

5. Momtaz H, Farzan R, Rahimi E, Safarpoor Dehkordi F, Souod N. Molecular characterization of Shiga toxin-producing Escherichia coli isolated from ruminant and donkey raw milk samples and traditional dairy products in Iran. Sci World J. 2012;2012:1-13.

6. Momtaz H, Dehkordi FS, Rahimi E, Ezadi H, Arab R. Incidence of Shiga toxin-producing Escherichia coli serogroups in ruminant's meat. Meat Sci. 2013;95:381-8

7. Dehkordi FS, Yazdani F, Mozafari J, Valizadeh Y. Virulence factors, serogroups and antimicrobial resistance properties of Escherichia coli strains in fermented dairy products. BMC research notes. 2014;7:217.

8. Bai $X$, Zhang W, Tang $X$, Xin $Y, X u Y$, Sun H, Luo X, Pu J, Xu J, Xiong Y. Shiga toxin-producing Escherichia coli in plateau pika (Ochotona curzoniae) on the Qinghai-Tibetan plateau, China. Front Microbiol. 2016;7:375.

9. Dhaka P, Vijay D, Vergis J, Negi M, Kumar M, Mohan V, Doijad S, Poharkar KV, Malik SS, Barbuddhe SB. Genetic diversity and antibiogram profile of diarrhoeagenic Escherichia coli pathotypes isolated from human, animal, foods and associated environmental sources. Infection Ecol \& Epidemiol. 2016:6:31055.

10. Wang J, Stanford K, McAllister TA, Johnson RP, Chen J, Hou H, Zhang G, Niu YD. Biofilm formation, virulence gene profiles, and antimicrobial resistance of nine serogroups of non-0157 Shiga toxin-producing Escherichia coli. Foodborne Pathog Dis. 2016;13:316-24

11. Farshad S, Ranijbar R, Japoni A, Hosseini M, Anvarinejad M, Mohammadzadegan R. Microbial susceptibility, virulence factors, and plasmid profiles of uropathogenic Escherichia coli strains isolated from children in Jahrom, Iran. Archives of Iranian Medicine (AIM). 2012;15:312-6.

12. Amézquita-López BA, Quiñones B, Soto-Beltrán M, Lee BG, Yambao JC, Lugo-Melchor OY, Chaidez C. Antimicrobial resistance profiles of Shiga toxin-producing Escherichia coli 0157 and non-O157 recovered from domestic farm animals in rural communities in northwestern Mexico. Antimicrob Resist Infect Control. 2016;5:1.

13. Abdi S, Ranjbar R, Vala MH, Jonaidi N, Bejestany OB, Bejestany FB. Frequency of bla TEM, bla SHV, bla CTX-M, and qnrA Among Escherichia coli Isolated From Urinary Tract Infection. Arch Clin Infect Dis. 2014:9:e18690.

14. IDF IDF. Milk and milk products - guidance on methods of sampling. In: IDF standard 50C, vol. Brussels, Belgium; 1995

15. Woo PC, Cheung EY. Leung K-W, Yuen K-y: identification by 165 ribosomal RNA gene sequencing of an Enterobacteriaceae species with ambiguous biochemical profile from a renal transplant recipient. Diagn Microbiol Infect Dis. 2001;39:85-93.

16. Sambrook J, Russell D. Molecular cloning: a laboratory manual, (pp3. 17-3. 32). Cold Spring Harbor: Cold Spring Harbor Laboratory Press; 2001.

17. Momtaz H, Karimian A, Madani M, Dehkordi FS, Ranjbar R, Sarshar M, Souod N. Uropathogenic Escherichia coli in Iran: serogroup distributions, virulence factors and antimicrobial resistance properties. Ann Clin Microbiol Antimicrob. 2013;12:8.

18. Momtaz H, Dehkordi FS, Hosseini MJ, Sarshar M, Heidari M. Serogroups, virulence genes and antibiotic resistance in Shiga toxin-producing Escherichia coli isolated from diarrheic and non-diarrheic pediatric patients in Iran. Gut pathogens. 2013;5:1.
19. Wayne P. Clinical and laboratory standards institute (CLSI) performance standards for antimicrobial disk diffusion susceptibility tests 19th ed. approved standard. CLSI document M100-S19, vol. 29; 2009.

20. Ombarak RA, Hinenoya A, Awasthi SP, Iguchi A, Shima A, Elbagory A-RM, Yamasaki S. Prevalence and pathogenic potential of Escherichia coli isolates from raw milk and raw milk cheese in Egypt. Int J Food Microbiol. 2016;221: 69-76.

21. Elhadidy M, Mohammed M. Shiga toxin-producing Escherichia coli from raw milk cheese in Egypt: prevalence, molecular characterization and survival to stress conditions. Lett Appl Microbiol. 2012;56:120-7.

22. Stephan R, Schumacher S, Corti S, Krause G, Danuser J, Beutin L. Prevalence and characteristics of Shiga toxin-producing Escherichia coli in Swiss raw milk cheeses collected at producer level. J Dairy Sci. 2008;91:2561-5.

23. Mohammadi P, Abiri R, Rezaei M, Salmanzadeh-Ahrabi S. Isolation of Shiga toxin-producing Escherichia coli from raw milk in Kermanshah, Iran. Iranian journal of microbiology. 2013,5:233.

24. Nobili G, Franconieri I, Basanisi M, La Bella G, Tozzoli R, Caprioli A, La SG. Isolation of Shiga toxin-producing Escherichia coli in raw milk and mozzarella cheese in southern Italy. J Dairy Sci. 2016;99:7877-80.

25. Zeinhom MM, Abdel-Latef GK. Public health risk of some milk borne pathogens. Beni-Suef University Journal of Basic and Applied Sciences. 2014 3:209-15.

26. Öksüz Ö, Arici M, Kurultay S, Gümüs T. Incidence of Escherichia coli 0157 in raw milk and white pickled cheese manufactured from raw milk in Turkey. Food Control. 2004;15:453-6.

27. Xi M, Feng Y, Li Q, Yang Q, Zhang B, Li G, Shi C, Xia X. Prevalence, distribution, and diversity of Escherichia coli in plants manufacturing goat milk powder in Shaanxi, China. J Dairy Sci. 2015;98:2260-7.

28. Quinto E, Cepeda A. Incidence of toxigenic Escherichia coli in soft cheese made with raw or pasteurized milk. Lett Appl Microbiol. 1997;24:291-5.

29. Momtaz H, Safarpoor Dehkordi F, Taktaz T, Rezvani A, Yarali S. Shiga toxinproducing Escherichia coli isolated from bovine mastitic milk: serogroups, virulence factors, and antibiotic resistance properties. Sci World J. 2012;2012

30. Llorente $\mathrm{P}$, Barnech L, Irino K, Rumi MV, Bentancor A. Characterization of Shiga toxin-producing Escherichia coli isolated from ground beef collected in different socioeconomic strata markets in Buenos Aires. Argentina BioMed research international. 2014;2014

31. Ranjbar R, Masoudimanesh M, Dehkordi FS, Jonaidi-Jafari N, Rahimi E. Shiga (Vero)-toxin producing Escherichia coli isolated from the hospital foods; virulence factors, o-serogroups and antimicrobial resistance properties. Antimicrobial Resistance \& Infection Control. 2017;6:4.

32. Farrokh C, Jordan K, Auvray F, Glass K, Oppegaard H, Raynaud S, Thevenot D, Condron R, De Reu K, Govaris A. Review of Shiga-toxin-producing Escherichia coli (STEC) and their significance in dairy production. Int J Food Microbiol. 2013:162:190-212.

33. Caro I, Mateo J, Rúa J, del Rosario García-Armesto M. Occurrence of Escherichia coli 0157, 0111 and $\mathrm{O} 26$ in raw ewe's milk and performance of two enrichment broths and two plating media used for its assessment. Int $J$ Food Microbiol. 2011:146:84-7.

34. Hemmatinezhad B, Khamesipour F, Mohammadi M, Safarpoor Dehkordi F, Mashak Z. Microbiological investigation of O-serogroups, virulence factors and antimicrobial resistance properties of Shiga toxin-producing Escherichia Coli isolated from ostrich, Turkey and quail meats. J Food Saf. 2015;35:491-500

35. Ayaz ND, Copuroglu G, Ormeci E, Oz B. Presence of Staphylococcus aureus and Shiga toxigenic Escherichia coli O157: H7 in raw meat in Ağrı Turkey. Int J Enteric Pathog. 2016:4:e36523.

36. Neher S, Hazarika A, Barkalita L, Borah P, Bora D, Sharma R. Isolation and characterization of Shiga toxigenic Escherichia coli of animal and bird origin by multiplex polymerase chain reaction. Veterinary world. 2016;9:123.

37. Mamza SA, Egwu GO, Mshelia GD. Antibiotic susceptibility patterns of betalactamase-producing Escherichia coli and Staphylococcus aureus isolated from chickens in Maiduguri (arid zone), Nigeria. Veterinarski Arhiv. 2010;80:283-97.

38. Tark D-S, Moon DC, Kang HY, Kim S-R, Nam H-M, Lee H-S, Jung S-C, Lim S-K Antimicrobial susceptibility and characterization of extended-spectrum B-lactamases in Escherichia coli isolated from bovine mastitic milk in South Korea from 2012 to 2015. J Dairy Sci. 2017;100:3463-9.

39. Disassa N, Sibhat B, Mengistu S, Muktar Y, Belina D: Prevalence and Antimicrobial Susceptibility Pattern of E. coli O157: H7 Isolated from Traditionally Marketed Raw Cow Milk in and around Asosa Town, Western Ethiopia. Veterinary medicine international 2017, 2017. 
40. Colello R, Etcheverría Al, Conza JAD, Gutkind GO, Padola NL. Antibiotic resistance and integrons in Shiga toxin-producing Escherichia coli (STEC). Braz J Microbiol. 2015;46:1-5.

41. Atapoor S, Dehkordi FS, Rahimi E. Detection of Helicobacter pylori in various types of vegetables and salads. Jundishapur J Microbiol. 2014;7:e10013.

42. Momtaz H, Dehkordi FS, Rahimi E, Asgarifar A, Momeni M. Virulence genes and antimicrobial resistance profiles of Staphylococcus aureus isolated from chicken meat in Isfahan province, Iran. J Appl Poultry Res. 2013;22:913-21.

43. Dehkordi FS, Parsaei P, Saberian S, Moshkelani S, Hajshafiei P, Hosseini SR, Babaei M, Ghorbani MN. Prevalence study of Theileria annulata by comparison of four diagnostic techniques in Southwest Iran. Bulgar J Vet Med. 2012;15:123-30.

44. Madahi H, Rostami F, Rahimi E, Dehkordi FS. Prevalence of enterotoxigenic Staphylococcus aureus isolated from chicken nugget in Iran. Jundishapur J Microbiol. 2013;7:e10237.

45. Rahimi E, Sepehri S, Dehkordi FS, Shaygan S, Momtaz H. Prevalence of Yersinia species in traditional and commercial dairy products in Isfahan Province. Jundishapur J Microbiol. 2014;7:e9249.

46. Momtaz H, Davood Rahimian M, Safarpoor DF. Identification and characterization of Yersinia enterocolitica isolated from raw chicken meat based on molecular and biological techniques, Iran. J Appl Poult Res. 2013; 22:137-45.

47. Safarpoor Dehkordi F, Barati S, Momtaz H, Hosseini Ahari SN, Nejat DS. Comparison of shedding, and antibiotic resistance properties of Listeria monocytogenes isolated from milk, feces, urine, and vaginal secretion of bovine, ovine, caprine, buffalo, and camel species in Iran. Jundishapur J Microbiol. 2013;6:284-94.

48. Ghorbani F, Gheisari E, Dehkordi FS. Genotyping of vacA alleles of Helicobacter pylori strains recovered from some Iranian food items. Trop J Pharm Res. 2016;15:1631-6.

49. Dehkordi FS, Khamesipour F, Momeni M. Brucella abortus and Brucella melitensis in Iranian bovine and buffalo semen samples: the first clinical trial on seasonal, senile and geographical distribution using culture, conventional and real-time polymerase chain reaction assays. Kafkas Univ Vet Fak Dergisi. 2014;20:821-8.

50. Dehkordi FS, Haghighi N, Momtaz H, Rafsanjani MS, Momeni M. Conventional vs real-time PCR for detection of bovine herpes virus type 1 in aborted bovine, buffalo and camel foetuses. Bulgar J Vet Med. 2013;16: 102-11

51. Dehkordi AH, Khaji L, Shahreza MHS, Mashak Z, Dehkordi FS, Safaee Y, Hosseinzadeh A, Alavi I, Ghasemi E, Rabiei-Faradonbeh M. One-year prevalence of antimicrobial susceptibility pattern of methicillin-resistant Staphylococcus aureus recovered from raw meat. Trop Biomed. 2017;34:396-404

52. Safarpoor FD, Gandomi H, Basti AA, Misaghi A, Rahimi E. Phenotypic and genotypic characterization of antibiotic resistance of methicillin-resistant Staphylococcus aureus isolated from hospital food. Antimicrob Res Infect Control. 2017:6:104.

53. Dormanesh B, Dehkordi FS, Hosseini S, Momtaz H, Mirnejad R, Hoseini MJ, Yahaghi $\mathrm{E}$, Tarhriz V, Khodaverdi DE. Virulence factors and o-serogroups profiles of uropathogenic Escherichia coli isolated from Iranian pediatric patients. Iran Red Cres Med J. 2014;16:e14627.

54. Shahrani M, Dehkordi FS, Momtaz H. Characterization of Escherichia coli virulence genes, pathotypes and antibiotic resistance properties in diarrheic calves in Iran. Biol Res. 2014;47:28.

55. Nejat S, Momtaz H, Yadegari M, Nejat S, Safarpour Dehkordi F, Khamesipour F. Seasonal, geographical, age and breed distributions of equine viral arteritis in Iran. Kafkas Univ Vet Fak Dergisi. 2015;21:111-6.

56. Dehkordi FS, Valizadeh Y, Birgani TA, Dehkordi KG. Prevalence study of Brucella melitensis and Brucella abortus in cow's milk using dot enzyme linked immuno sorbent assay and duplex polymerase chain reaction. J Pure Appl Microbiol. 2014;8:1065-9.

57. Rahimi E, Yazdanpour S, Dehkordi FS. Detection of Toxoplasma gondii antibodies in various poultry meat samples using enzyme linked immuno sorbent assay and its confirmation by polymerase chain reaction. J Pure Appl Microbiol. 2014;8:421-7.

58. Yahaghi E, Khamesipour F, Mashayekhi F, Safarpoor Dehkordi F, Sakhaei MH, Masoudimanesh M, Khayyat Khameneie M. Helicobacter pylori in vegetables and salads: genotyping and antimicrobial resistance properties. BioMed Res Int. 2014;2014:1-11
59. Ranjbar R, Karami A, Farshad S, Giammanco GM, Mammina C. Typing methods used in the molecular epidemiology of microbial pathogens: a how-to guide. New Microbiol. 2014;37:1-15.

60. Jahandeh N, Ranjbar R, Behzadi P, Behzadi E. Uropathogenic Escherichia coli virulence genes: invaluable approaches for designing DNA microarray probes. Cent European J Urol. 2015;68:452-8.

61. Tajbakhsh E, Khamesipour F, Ranjbar R, Ugwu IC. Prevalence of class 1 and 2 integrons in multi-drug resistant Escherichia coli isolated from aquaculture water in Chaharmahal Va Bakhtiari province, Iran. Ann Clin Microbiol Antimicrob. 2015;14:37

62. Farshad S, Ranjbar R, Japoni A, Hosseini M, Anvarinejad M, Mohammadzadegan R. Microbial susceptibility, virulence factors, and plasmid profiles of uropathogenic Escherichia coli strains isolated from children in Jahrom, Iran. Arch Iran Med. 2012;15:312-6.

63. Anvarinejad M, Farshad Sh, Ranjbar R, Giammanco GM, Alborzi A, Japoni A. Genotypic Analysis of E. coli Strains Isolated from Patients with Cystitis and Pyelonephritis. Iran Red Crescent Med J. 2012;14:408-16.

64. Ranjbar, R, Haghi-Ashtiani, MT, Jafari, NJ, Abedini, M. The prevalence and antimicrobial susceptibility of bacterial uropathogens isolated from pediatric patients. Iran J Publ Health. 2009;38:134-8.

65. Khademestarki NS, Ranjbar R. The Phylogenetic Study of Escherichia coli Strains Isolated from Clinical Cases. J Pure Appl Microbiol. 2016:10:351-4

66. Ranjbar R, Hosseini S, Zahraei-Salehi T, Kheiri R, Khamesipour F. Investigation on prevalence of Escherichia coli strains carrying virulence genes ipaH, estA, eaeA and bfpA isolated from different water sources. Asian Pacific J Trop Dis. 2016;6:278-83.

67. Behzadi P, Najafi A, Behzadi E, Ranjbar R. Microarray long oligo probe designing for Escherichia coli: An in-silico DNA marker extraction. Central Eur J Urol. 2016;69:105-11.

68. Ranjbar R, Ahmadnezhad B, Jonaidi N. The prevalence of beta lactamase producing Escherichia coli strains isolated from the urine samples in Valiasr Hospital. Biomed Pharmacol J. 2014;7:425-431.

69. Farshad S, Anvarinejad M, Tavana AM, Ranjbar R, Japoni A, Zadegan RM, Alborzi A. Molecular epidemiology of Escherichia coli strains isolated from children with community acquired urinary tract infections. Afr J Microbiol Res. 2011:5:4476-83.

70. Anvarinejad M, Farshad S, Alborzi A, Ranjbar R, Giammanco GM, Japoni A Integron and genotype patterns of quinolones-resistant uropathogenic Escherichia coli. Afr J Microbiol Res. 2011;5:3765-70.

71. Ranjbar R, Behzadi P, Najafi A, Roudi R. DNA microarray for rapid detection and identification of food and water borne bacteria: from dry to wet lab. Open Microbiol J. 2017;11:330-8.

72. Ranjbar R, Sami M. Genetic Investigation of beta-lactam associated antibiotic resistance among Escherichia coli strains isolated from water sources. Open Microbiol J. 2017;11:203-10.

73. Ranjbar R, Farahani O. The Prevalence of plasmid-mediated quinolone resistance genes in Escherichia coli isolated from hospital wastewater sources in Tehran, Iran. Iran J Public Health. 2017:46:1285-91.

74. Ranjbar R, Pezeshknejad P, Khamesipour F, Amini K, Kheiri R. Genomic fingerprints of Escherichia coli strains isolated from surface water in Alborz province, Iran. BMC Res Notes. 2017;10:295.

\section{Ready to submit your research? Choose BMC and benefit from:}

- fast, convenient online submission

- thorough peer review by experienced researchers in your field

- rapid publication on acceptance

- support for research data, including large and complex data types

- gold Open Access which fosters wider collaboration and increased citations

- maximum visibility for your research: over $100 \mathrm{M}$ website views per year

At BMC, research is always in progress.

Learn more biomedcentral.com/submissions 